\title{
Лемковские анафорические местоимения: кодифицированная норма и разговорный узус
}

К л ю че в ы е с ло в а : лемковский язык; кодификация; узус; словоизменение; анафорические местоимения

Key words: Lemko language; codification; usage; inflection; anaphoric pronouns

\section{1. Введение}

В силу определённых географических, политических, исторических и социальных факторов лемковский (или лемковско-русинский) язык ${ }^{1}$, на протяжении нескольких столетий функционировавший на периферии восточнославянского диалектного континуума, оказался в очень непростой ситуации: в результате принудительных переселенческих акций, проведённых в 1945-47 гг., лемки были рассредоточены по различным регионам Польши и Украины, из-за чего лемковская диалектная структура была практически разрушена - несмотря на то, что

1 Употребление здесь и далее по отношению к идиому лемков/ русинов понятия «язык» не означает, что его можно квалифицировать как «полноценный» литературный язык, отвечающий схеме признаков литературного языка, выдвинутой в своё время Исаченко. 
небольшая часть лемков позже вернулась на родину, говорить о компактном лемковском населении на исторической Лемковщине (т.е. на юго-востоке сегодняшней Польши) уже не приходится. К этому можно добавить и ещё одно неблагоприятное обстоятельство: лемки считают себя частью русинского народа ${ }^{2}$, не имеющего собственного государства и разделённого к тому же границами различных европейских государств - русины проживают сегодня не только в Польше, но и на югозападе Украины и на северо-востоке Словакии ${ }^{3}$. Часть русинов, кроме того, проживает в Воеводине (на территории бывшей Югославии), куда

2 Важно отметить, что всех лемков (как и русинов вообще) можно условно разделить, как минимум, на два лагеря: на «лемков-автономистов» (т.е. лемков-русинов), считающих себя отдельной нацией, а (лемковско-)русинский - самостоятельным языком, и на «лемков-украинцев», считающих себя (и других русинов) частью украинской нации, а свой язык - диалектом украинского (лемковский - наряду с гуцульским и бойковским диалектами - традиционно причисляется к карпатской группе южнозападных диалектов украинского языка. Cp. Kuraszkiewicz 1954: 65/ Rieger 2004: 39). Кроме того, всё ещё встречаются и представители русофильской ориентации (cp. Magosci 2006: 211; подробнее о вопросе и проблематике национальной самоидентичности русинов см. Michna 2004: 283-309). Подобный дуализм самоидентификации русинов берёт своё начало ещё в XIX веке: восточные славяне, жившие тогда в восточной Галиции и северной Буковине (т.е. на территории Габсбургской Империи), как и карпатские русины, также называли себя русинами (нем. Rus(s)inen, Ruthenen), но в отличие от последних уже в начале XX века начали идентифицировать себя с украинцами. Так, практически все «русины» из Галичины и Буковины считают себя сегодня украинцами, а свой язык - украинским, в то время как бо́льшая часть русинов (или «руснаков») из Карпатской Руси считают себя отдельной нацией (подробнее см. Магочій 2004: 17). Одним из важных факторов, обусловивших такое расслоение в русинском обществе, является также и осуществлённая в послевоенное время ассимиляционная политика СССР, заключавшаяся в насильственной украинизации русинов (подробнее см. Падяк 2006: 266-269; Michna 2004: 79-86, а также Magosci 2006: 210/ 2004: 33-35). Следует отметить также и то, что и в лингвистическом дискурсе до сих пор не существует единого мнения о том, что собственно представляет собой лемковский язык начиная с неясного происхождения этого языка из довольно гетерогенного в диалектном плане Карпатского региона (см. Магочій 2004: 22-25) и заканчивая его социолингвистическим статусом (подробнее см. Misiak 2006: 106-134). Напр., Дуличенко (2006: 41-44) различает между югославо-русинским (в Воеводине) и карпато-русинским литературными микроязыками (последний объединяет в себе пряшевский, лемковский и закарпатский национальные варианты).

3 Небольшая часть русинов проживает сегодня в Венгрии и Румынии, кроме того, существуют также русинские диаспоры в США, Канаде и Аргентине. Ср. Магочій 2004: 16. 
они переселились в XVIII веке. Такое многовековое соседство с другими славянскими (и неславянскими) народами, а значит, с их языками и диалектами, явно доминирующими и в актуальной контактной ситуации каждого из национальных вариантов русинского языка, во многом определелило их дальнейшее развитие и послужило источником многочисленных интерференций, прослеживающихся не только на лексическом и фонетическом, но и на морфологическом уровне. Всё это, как известно, может привести не только к высокой вариантности на всех языковых структурных уровнях, но и к таким феноменам, как переключение кодов, смешанная речь, или даже к развитию нового, смешанного идиома. Всё чаще в научной литературе в связи с русинским языком и его национальными вариантами упоминается и понятие «языкового изменения» (нем. Sprachwandel), обусловленного контактами с другими языками ${ }^{4}$.

Все названные выше факторы, в свою очередь, дополнительно осложняют и без того сложный процесс кодификации русинского литературного языка, ведь за исключением сравнительно небольшой русинской группы в Воеводине, ещё в 1923 году кодифицировавшей свой вариант, известный в славистике как югославо-русинский (или воеводинский) литературный (микро)язык, другим русинским группам до падения коммунистического режима так и не удалось настолько нормировать свои варианты, чтобы ими можно было пользоваться во всех сферах повседневной жизни. Только после 1989 года русины во всех странах смогли посвятить себя (вос)становлению своей этно-культурной и языковой автономии. Так, в 1992 году на съезде, впоследствии вошедшим в историю как Первый конгресс русинского языка, было решено создать три региональных варианта литературного русинского

${ }^{4}$ Напр., Тойч, сравнивая в своей работе словоизменительные системы пряшевского русинского, польского, словацкого и украинского, приходит к выводу, что русинский язык намного более близок к западнославянским языкам, чем к украинскому. По его словам, здесь мы имеем дело со случаем, когда под влиянием географической близости и, соотв., языковых контактов прежнее (более близкое) родство с восточнославянскими языками «проходит» и возникает новое - с западнославянскими языками. Таким образом, граница между восточной и западной Славией сдвигается дальше на восток, что, согласно Тойчу, приводит к возникновению нового диалектного континуума (cp. Teutsch 2001: 211). См. также Rabus (2011) и Pugh (2009). 
языка в Польше, Словакии и на Украине (соотв. лемковкий, пряшевский и закарпатский варианты $)^{5}$, к которым позже должен был присоединиться уже существующий кодифицированный и хорошо нормированный воеводинский, чтобы на основе всех этих четырёх вариантов сформировать общерусинское койне (ср. Магочій 2004: 110).

Об общерусинском койне на сегодняшний день не может быть и речи, однако на региональном уровне удалось добиться немалых, хотя и существенно отличающихся от региона к региону успехов: например, на Украине (в стране, где проживает большинство русинов) процесс стандартизации протекает наиболее проблематично. Попытки кодификации закарпатского варианта, предпринятые в 1999 и 2005 годах, не увенчались успехом: выпущенные грамматики по различным причинам не были признаны в академических кругах ${ }^{6}$. Кроме того, вплоть до принятия в 2012 году «закона о языках» ${ }^{7}$ Украинское государство не признавало ни русинской национальности, ни русинского языка ${ }^{8}$, а все попытки проявления русинской национальной автономии воспринимало как угрозу целостности Украины, обвиняя русинов в сепаратизме и проведении антиукраинской политики.

5 Каждый из этих вариантов должен был опираться «на живой языковой материал» своего региона.

6 Более подробно об этом см. Падяк (2006: 265-283), а также Michna (2004: 276$-280)$.

7 Ср. Закон Украины об основах государственной языковой политики (укр. 3aкон України про засади державної мовної політики). Ситуация вокруг подписания Януковичем в августе 2012 года этого «скандального» закона была широко освещена как в украинских, так и в российских СМИ. Многие сомневаются, что ситуация национальных меньшинств изменится благодаря ему в лучшую сторону, и считают, что на самом деле этот закон направлен на поддержку русского языка: согласно ему (ст. 7, ч. 2), наряду с русинским и 16 другими языками, и русский язык официально признаётся региональным языком, а следовательно снова приобретает в пределах Украины определённый правовой статус.

8 Украинские общественные деятели (как и русины-украинцы) отрицают существование русинской нации, утверждая, что русины - это всего лишь региональная группа украинского народа с самобытным фольклором. Такая реакция украинцев на русинскую языковую и этническую самоидентификацию в какой-то степени парадоксальна: сегодняшняя ситуация русинов очень напоминает ситуацию самих украинцев, которым в свое время также пришлось бороться за право называть себя отдельным народом, а свой язык - отдельным языком (см. также Michna 2004: 283-308). 
В то же время в других регионах ситуация вокруг кодификации складывается намного благоприятнее. Самыми успешными в этом плане можно считать словацких русинов: им первым удалось кодифицировать свой, пряшевский вариант русинского языка, который был официально провозглашён в 1995 году. Лемкам в Польше также удалось кодифицировать свой вариант русинского: в 2000 году9 Генриком Фонтанским $^{10}$ и Мирославой Хомяк была опубликована «Gramatyka języka łemkowskiego. Граматыка лемківского языка», переработанное издание которой вышло в 2004 году ${ }^{11}$.

Но если по отношению к пряшевскому варианту русинского можно утверждать, что это не надуманная «академическая конструкция» и что его литературный вариант на самом деле употребляется как в устной, так и в письменной речи (cp. Rabus 2011: 423) ${ }^{12}$, то утверждать это по отношению к лемковскому языку было бы, по меньшей мере, преждевременным, тем более что исследования в этом направлении до сих пор не проводились ${ }^{13}$.

Настоящая статья посвящается лемковской морфологии, а именно словоизменению лемковских анафорических местоимений. Т.к. в на-

9 Первой попыткой кодификации лемковского языка можно считать «Периу траматыку лемківского языка» Мирославы Хомяк, изданную на правах рукописи ещё в 1992 году Ассоциацией Лемков (лем. Стоваришыня Лемків).

10 Автор статьи выражает огромную благодарность проф. Фонтанскому (Силезский Университет, Катовице) за любезно предоставленную ей необходимую информацию.

${ }^{11}$ Как в Словакии, так и в Польше с тех пор было издано множество словарей, различных учебников и т.д. Оба варианта преподаются в школах и университетах, широко используются в печати и в культурном секторе (cp. Michna 2004: 271/ Misiak 2006: 112-124).

${ }^{12}$ В своей устной форме близкий к стандарту вариант пряшевского русинского обслуживает пока только определённые функциональные сферы.

13 Процесс кодификации лемковского в Польше завершился намного позже, чем процесс кодификации пряшевского русинского в Словакии. Михна в своём исследовании приходит к выводу, что на Лемковщине языковой вопрос играл не такую важную роль, как в других регионах. Это объясняется тем, что у лемков не было давления из вне: в отличие от словацких русинов, для которых создание кодифицированной нормы имело и «практическую ценность», т.к. было условием для получения ими определённого правового статуса в пределах Словакии (а значит, и государственной поддержки), кодификация для лемков в Польше была скорее символическом актом, т.к. и без неё они имели право вести как преподавательскую, так и издательскую деятельность (Michna 2004: 276). 
стоящий момент не совсем ясно, насколько кодифицированная норма лемковского языка отражает речь его носителей (а скорее всего можно исходить из наличия определённых расхождений между инвентарём грамматических форм, описанных в кодифицированном варианте, и реальной языковой действительностью), акцент ниже делается на выявлении сходств и различий между парадигмой местоимённых форм, представленной в лемковской грамматике, и формами, употребление которых характерно для узуса разговорной лемковской речи. Основой для сравнительного анализа послужил корпус лемковской (устной) речи, состоящий из разговоров, зафиксированных в семейном кругу ${ }^{14}$. Корпус, включающий в себя в общей сложности около 196.000 словоформ, состоит из двух подкорпусов, данные для которых собирались с 1994 по 1996 год, а также в 2010 году в двенадцати различных населённых пунктах Польши. Данное исследование основывается на языковом материале из более «позднего» подкорпуса, содержащего ок. 95.000 словоформ ${ }^{15}$.

14 Этот корпус, представляющий собой набор транскрибированных аудиозаписей, объединённых в реляционную базу данных, был составлен в рамках текущего ольденбургского проекта «Словоизменительные иррегулярности в актуальных контактных разновидностях севернославянских языков», осуществляемого под руководством проф. док. Г. Хентшеля при финансовой поддержке Немецкого Исследовательского Сообщества (нем. Deutsche Forschungsgesellschaft). Аудиозаписи с языковым материалом были любезно предоставлены проф. док. Я. Ригером (Институт польского языка, ПАН, Варшава).

15 Записи для этого подкорпуса проводились в 2010 году в Лосях, Блехнарке, Ханьчове, Маластуве, Гладышуве, Ропице и Горлицах (Горлицкий повят, Малопольское воеводство). Следует отметить, что почти все записанные респонденты $(98,2 \%)$ являются представителями среднего и молодого поколения носителей лемковского языка (1945-1993 годы рождения). Подробнее о корпусе и респондентах см. Menzel/Reis (в печати). 


\section{2. Детали сопоставительного анализа}

В исследуемом корпусе зафиксировано 1.674 случая употребления анафорических местоимений (wordtokens), из них - 958 употреблений форм именительного падежа и 716 - косвенных падежей ${ }^{16}$.

a) И мен и те льны й п а деж. Как известно, склонение личных местоимений в славянских языках носит специфический характер: при образовании форм именительного и косвенных падежей наблюдается супплетивизм. В случае с анафорическими местоимениями этот супплетивизм возник ещё в праславянском языке в результате слияния двух парадигм указательных местоимений опъ и jb. Формы косвенных падежей восходят при этом к местоимению $j b$ с адъективным, а формы именительного падежа к местоимению опь ${ }^{17}$ с субстантивным типом склонения.

\begin{tabular}{|c|c|c|c|c|c|c|c|c|c|c|c|}
\hline \multicolumn{3}{|c|}{ м.p./cp.p. } & \multicolumn{5}{c|}{ ж.p. } & \multicolumn{4}{c|}{ мн.ч. } \\
\hline грамм. & корп. & $\mathbf{n}$ & $\%$ & грамм. & корп. & n & $\%$ & грамм. & корп. & n & \% \\
\hline v'in & $v^{\prime}$ in & 347 & 86,1 & ona & & 317 & 99,4 & ony & оny & 205 & 91,1 \\
\hline & $\begin{array}{c}\text { úin/w'in/ } \\
\text { win }\end{array}$ & 38 & 9,4 & & wona & 2 & 0,6 & & on'i & 13 & 5,8 \\
\hline on & 18 & 4,5 & & & & & & one & 7 & 3,1 \\
\hline ono & ono & 11 & 100 & & & & & & & & \\
\hline
\end{tabular}

Таблица 1. Анафорические местоимения в именительном падеже

В качестве форм именительного падежа в лемковской грамматике поданы формы v'in, ona, ono в ед.ч. и ony во мн.ч. Помимо своих специфических родовых окончаний эти формы различаются наличием или

16 Для более наглядной демонстрации фонетических и фонологических особенностей все местоимённые формы здесь и далее представлены в виде транскрипции на основе латинской графики.

17 Только один славянский язык является в данном случае исключением: в болгарском формы И.п. восходят к праславянскому указательному местоимению $t$ zjb. См. Townsend 2002: 142. 
отсутствием протетического v-, причём с протезой выступает только форма мужского рода. Как известно, протетические звуки в абсолютном начале слова возникли ещё в дописьменный период. При этом в качестве протезы чаще всего выступали сонанты $j$ - и $w$ - (v-), распределявшиеся, как правило, в соответствии с законом слогового сингармонизма: гласные переднего ряда притягивали к себе $j$-, а гласные заднего ряда - w- (Townsend 2002: 54-55). Появление протетического $v$ - перед $i$ (т.е. перед гласным переднего ряда) у формы м.p. v’in - как и в украинском языке - объясняется тем, что развился он вероятно перед этимологическим $\dot{o}$, когда оно ещё произносилось как дифтонг с первым компонен-

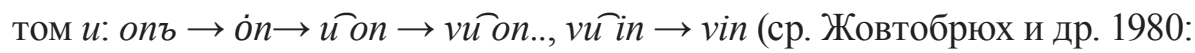
$99)^{18}$. Как видно из таблицы 1 , помимо формы $v^{\prime}$ in в исследуемом корпусе зафиксированы и другие формы с протезой: úin, w'in и win в мужском роде (всего 38 употреблений) и жоna (только 2 употребления) - в женском, причём в качестве протезы во всех этих случаях выступают билабиальные $u$ - или $w$-. Согласно Филину (2006: 290-296), чередование в анлауте билабиального $w$-(u-) и лабиодентального $v$ - в юго-западной части восточнославянского диалектного ареала является довольно распространённым феноменом. Не исключено в данном случае и западнославянское влияние, т.к. анафорические местоимения с протезой часто встречаются и в малопольских, и в восточнословацких говорах ${ }^{19}$. Кро-

18 В украинском языке протетический $v$ - распространился и на другие формы именительного падежа (cp. укр. vona, vono, vony). В лемковском такого аналогического выравнивания не произошло (или же протезы перед -о были утрачены).

19 Нитшем (Nitsch 1960) в малопольских диалектах были отмечены такие формы, как vun и vuni с лабиодентальным v- и won, wun, wona, wuna и woni с билабиальным $w$ - в качестве протезы (этот труд Нитша, представляющий собой собрание диалектных текстов со всей территории Польши, послужил автору данной статьи своего рода «корпусом» малопольских диалектов, с помощью которого была составлена парадигма анафорических местоимений, употребление которых характерно для малопольских говоров). Такая лабиализация, т.е. появление в анлауте билабиального $w$-(ú-) перед о и $u$ (напр. u्रokno, u्रorać), является характерной чертой малопольских, великопольских и силезских диалектов (EWJP 1978: 324). В случае с протезой в лемковских формах v'in/ úin, w'in мы имеем дело с уже морфонологизированным явлением, исторически восходящим к активному фонетическому процессу. Чередование $v$ - и $w$-/ú-перед $i$, несмотря на то что лабиализация происходит только перед гласными заднего ряда $(/ \mathrm{i} / \mathrm{\rightarrow} \rightarrow$ [-лабиал.], /o,u/ $\rightarrow$ [+лабиал.]), в данном случае можно скорее всего объяснить тем, что здесь произошла генерализация, т.е. распространение билабиальной протезы на формы с корневой глас- 
ме того, в корпусе содержится 18 употреблений формы м.р. оп и 11 примеров употребления формы опо для ср.р. (обе формы соответствуют формам И.п. ед.ч. м.р. и, соотв., ср.р. как в польском, так и в словацком языке).

Что же касается множественного числа, то здесь корпус показывает три различные формы: ony, on'i и one. Форма ony (205 употреблений), поданная для И.п. мн.ч. и в лемковской грамматике, в корпусе явно преобладает. Употребление форм on'i и опе обусловлено, по-видимому, воздействием со стороны польского языка. Несмотря на то что эти формы в меньшинстве (13 и 7 примеров), нельзя не обратить внимание на тот факт, что влияние польского в данном случае отразилось не только на формальной, но и на функциональной стороне: в то время как форма on' $i$ употребляется в корпусе только по отношению к мужским или смешанным группам, форма опе используется исключительно в неличномужском контексте. Ony же употребляется во всех контекстах, т.е. здесь не происходит характерного для польского (и словацкого) языка деления на лично-мужской и женско-вещной род во мн.ч.

В целом, исследуемый корпус подтверждает парадигму И.п., предложенную лемковской грамматикой: форма v’in предпочитается в 86,1\%, ono в 100\%, ona в 99,4\%, а форма ony - в 91,1\% всех случаев.

б) Р оди тельны й па деж. Для м.p./cp.p. в лемковской грамматике представлены следующие формы анафорических местоимений: краткая форма ho, «полная» форма joho, а также две формы с начальным $n$-, употребляющиеся после предлогов, n'oho и neho. Как видно из таблицы 2 , все эти формы присутствуют и в корпусе ${ }^{20}$, однако, что

ной -i- (т.е. с икавизмом) по аналогии с другими формами, где лабиализация выступает закономерно. Что же касается восточнословацких диалектов, то протетический $v$ - широко распространён в их восточной части (Латта 1991: карты 24/25), в анафорических местоимениях протеза $v$-, как и в украинском, выступает также во всех формах им.п. (Teutsch 2001: 121).

20 Приведённая в таблице 2 форма hо объединяет в себе 5 словоупотреблений формы ho и 1 словоупотребление формы хо, которая (наряду с формой go) рассматривается как один из возможных фонетических вариантов формы ho. Дело в том, что в отличие от польского языка в лемковском языке (как в украинском и словацком) в славянских по происхождению словах отсутствует взрывной $[\mathrm{g}]-$ ему со-

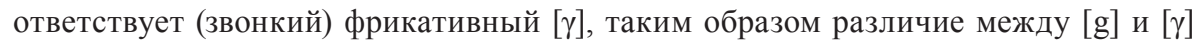
в этих языках чисто фонетическое. Что же касается лемковского, то частью этой 
касается форм на $n$-, то предпочтение явно отдаётся форме n'oho с 38 случаями употребления (ср. neho - всего 3 примера) ${ }^{21}$. Таким образом, в корпусе произошла своего рода «коррекция» избыточной парадигмы, предложенной в грамматике.

\begin{tabular}{|c|c|c|c|c|c|c|c|c|c|c|c|}
\hline \multicolumn{4}{|c|}{ м.p./cp.p. } & \multicolumn{4}{|c|}{ ж.p. } & \multicolumn{4}{|c|}{ мн.ч. } \\
\hline грамм. & корn. & n & $\%$ & грамм. & корп. & $\mathbf{n}$ & $\%$ & грамм. & корп. & $\mathbf{n}$ & $\%$ \\
\hline ho & ho/xo & 6 & 66,7 & jej & jej & 3 & 60 & ix & $i x / i h$ & 14 & 93,3 \\
\hline joho & joho & 3 & 33,3 & & $j i j$ & 2 & 40 & & n'ix & 1 & 6,7 \\
\hline \multicolumn{12}{|c|}{ после предлога } \\
\hline n'oho & n'oho & 38 & 92,7 & nej & - & - & - & nyx* & $n y x$ & 26 & 96,3 \\
\hline \multirow[t]{2}{*}{ neho } & neho & 3 & 7,3 & & n'ej & 27 & 87,1 & & n'ix & 1 & 3,7 \\
\hline & & & & & $n^{\prime} i j$ & 4 & 12,9 & & & & \\
\hline
\end{tabular}

Таблица 2. Анафорические местоимения в родительном падеже

Парадигму женского рода Р.п. в лемковской грамматике представляют формы јеј и пеј. Обращение к материалам корпуса открывает, однако, совсем другую картину: в беспредложных конструкциях употребляются (слабо представленные в корпусе) формы јеј и jij, в конструкциях с предлогами предпочтение отдаётся форме n'ej с палатализованным n- (27 примеров), употребление которой можно объяснить только западнославянским влиянием - эта форма соответствует форме ж.р. ед.ч. Р.п. в польском и словацком языках и, к тому же, встречается как в малопольских (Nitsch 1960), так и в восточнословацких (Панькевич 1938: 270) диалектах. Кроме того, в корпусе зафиксировано также и употребление формы $n^{\prime} i j$ (4 раза), которая - как и $j i j$ - также встречается в ма-

вариации, судя по всему, является и глухой фрикативный [х], т.к. в корпусе отмечен целый ряд случаев чередования $[\mathrm{g}],[\gamma]$ и $[\mathrm{x}]$ в различных позициях: напр. grupa - hrupa, gośći - hośći, jegomość - jehomość - jexomość, dlatoho - dlatoxo, mohtam moxłam и т.д. Различия такого типа (т.е. различия на фонетическом уровне) в данном исследовании игнорируются.

21 Низкая частотность употребления форм ho и јоһo объясняется тем, что в родительном падеже чаще всего выступают местоимения на $n$-, т.к. он употребляется в основном в предложных конструкциях, в то время как энклитические формы и формы на $j$ - выступают, как правило, в качестве прямого дополнения (чаще всего в винительном падеже). 
лопольских диалектах. Заданная грамматикой форма пеј корпусом не подтверждается.

Во мн.ч. согласно лемковской грамматике и в предложном, и в беспредложном контекстах должна употребляться только одна форма - $i x$. Судя по всему, это просто опечатка: как в примерах, так и в тексте самой грамматики в предложном контексте мн.ч. Р.п. употребляется форма пyx. Это подтверждается и корпусом: в контексте без предлога явное предпочтение отдаётся форме $i x$, но в предложном контексте - по аналогии со всеми «соседними» языками - употребляется форма пух с начальным $n$-. Кроме того, в корпусе в обоих контекстах (!) зафиксировано по одному примеру употребления «польско-словацкой» формы $n$ ' $i x$ с палатализованным $n$-.

в) В и н и тельны й п а деж. В лемковской грамматике формы анафорических местоимений мужского и среднего рода в Р.п. и В.п. (т.е. ho, joho - neho, n'oho) совпадают. Как видно из таблицы 3, все эти формы (с различной частотностью употребления) присутствуют в корпусе и в винительном падеже: в беспредложном контексте явно преобладает энклитическая форма ho (65 примеров), полная форма joho (с 2 примерами употребления) представлена в корпусе слабо; кроме того, здесь зафиксирован и 1 случай употребления формы jeho с тематической гласной -е-. В предложном контексте, слабо представленном в корпусе, так же, как и в Р.п., вырисовывается тенденция к употреблению формы n'oho с тематическим -o-. Заданная грамматикой форма пеho с тематической гласной -e- и на этот раз представлена в корпусе только 1 примером, как и «словацкая» форма n'eho с палатализованным $n$-.

\begin{tabular}{|c|c|c|c|c|c|c|c|c|c|c|c|}
\hline \multicolumn{4}{|c|}{ м.p./cp.p. } & \multicolumn{4}{|c|}{ ж.p. } & \multicolumn{4}{|c|}{ Мн.Ч. } \\
\hline грамм. & корп. & $\mathbf{n}$ & $\%$ & грамм. & корп. & $\mathbf{n}$ & $\%$ & грамм. & корп. & $\mathbf{n}$ & $\%$ \\
\hline ho & ho & 65 & 95,6 & jej & jej & 49 & 63,6 & ix & $i x$ & 30 & 96,8 \\
\hline joho & joho & 2 & 2,9 & ju & ju & 19 & 24,7 & & jix & 1 & 3,2 \\
\hline & jeho & 1 & 1,5 & & $j i$ & 5 & 6,5 & & & & \\
\hline & & & & & $j i j$ & 2 & 2,6 & & & & \\
\hline & & & & & jõ/jom & 2 & 2,6 & & & & \\
\hline
\end{tabular}




\begin{tabular}{|c|c|c|c|c|c|c|c|c|c|c|c|}
\hline \multicolumn{9}{|c|}{ м.р./cp.p. } & \multicolumn{9}{c|}{ ж.р. } & \multicolumn{5}{c|}{ мн.ч. } \\
\hline n'oho & n'oho & 5 & 71,4 & n'u & $n^{\prime} u$ & 11 & 61,1 & nyx & nyx & $\mathbf{5}$ & $\mathbf{1 0 0}$ \\
\hline neho & neho & 1 & 14,3 & & $n^{\prime} e j$ & 3 & 16,7 & & & & \\
\hline & n'eho & 1 & 14,3 & & n'ij & 2 & 11,1 & & & & \\
\hline & & & & $\begin{array}{c}\text { n'om/- } \\
-w\end{array}$ & 2 & 11,1 & & & & \\
\hline
\end{tabular}

Таблица 3. Анафорические местоимения в винительном падеже

Парадигма женского рода отличается в корпусе ещё более высокой вариантностью, чем парадигма мужского/среднего рода: для В.п. ед.ч. зафиксировано употребление 9 различных форм (word types): jej - n'ej, $j u-n^{\prime} u, j i-j i j-n^{\prime} i j$, а также jõ/jom - n'om/n'ow. ${ }^{22}$ Но и парадигма, представленная в лемковской грамматике, опять же является избыточной: на этот раз в ней приведены два различных варианта для беспредложного контекста јеj и $j u$, а также форма $n$ 'u с начальным $n$-. Тем не менее, в плане преференций корпус показывает довольно ясную картину: в беспредложном контексте предпочтение определённо отдаётся форме jej $(63,6 \%, 49$ словоупотреблений), вариант которой с начальным $n$ - (n'ej - 87,1\%) лидировал и в Р.п. Получается, что омонимия Р.п.=В.п. действительна в корпусе и для парадигмы женского рода, - это явление характерно для всех восточнославянских языков. Кроме того, зафиксировано употребление формы $j u^{23}(24,7 \%)$, для форм с диалектальной окраской $j i$ и $j i j$ с тематической гласной - $i$ - корпус даёт 5 и, соотв., 2 примера $^{24}, 2$ раза употребляется «польская» форма jõ/jom. Таким образом,

22 Формы jom - n'om/n'ow с деназализованным/ расчленённым носовым гласным в ауслауте рассматриваются здесь как возможные варианты реализации польских форм $j \tilde{o}-n^{\prime} j \tilde{o}$. Подробнее о процессе деназализации в польском стандарте и в польских диалектах см. EWJP (1978: 226).

23 Следует учесть тот факт, что предпочтение формы ји (с 19 примерами - второй по частоте употребления в данном контексте) носит относительный характер, т.к. в 17 из 19 случаев она употребляется одним и тем же респондентом. Это говорит о том, что форма јеј лидирует в корпусе с более чем трёхкратным перевесом.

24 Форма $j i$ широко распространена во всех соседних диалектах: в малопольских (Nitsch 1960: 126), в северной части восточнословацких (Панькевич 1938: 272) и в западных украинских (Kuraszkiewicz 1954: 71). Что же касается форм $j i j-n$ ' $i j$, 
в корпусе снова устраняется характерная в данном случае для лемковской грамматики редундантность. Что касается форм на $n$-, то в корпусе они представлены более слабо: здесь зафиксировано 11 примеров употребления формы $n$ 'u, а также 3 случая употребления формы $n^{\prime} e j$ и по 2 случая - n'ij и n'om/n'ow.

Во мн.ч. действует аналогичная тенденция, как и в парадигме Р.п.: в беспредложном контексте (за исключением единственного случая употребления йотированной формы $j i x^{25}$ ) употребляется заданная грамматикой форма ix (96,8\%), а в контексте после предлога - как и в Р.п. - в корпусе появляется не учтённая в грамматике форма $n y x$ с начальным $n-26$.

Результаты исследования на данном этапе показывают, что омонимия Р.п.=В.п. распространяется в корпусе как на формы ед.ч. во всех родах, так и на формы мн.ч. В связи с этим не всегда удаётся однозначно определить падеж форм, «типичных» здесь для обоих падежей (jo -joho - n'oho, jej - n'ej, $i x-n y x)$. Особенно чётко эта проблематика проявляется в контексте при переходных глаголах с отрицанием: если в польском языке падежом прямого дополнения при глаголах с отрицанием может быть исключительно родительный, а в современном словацком, напротив, предпочитается винительный, то, например, в украинском языке (как и в русском) ситуация уже более сложная. Так, и в случае с лемковским языком нельзя исходить из того, что для него характерно консеквентное употребление родительного падежа в качестве падежа дополнения после глаголов с отрицанием: в корпусе в этом контексте зафиксировано употребление и винительного падежа.

Случаи употребления анафорических местоимений после глаголов с отрицанием, падеж которых нельзя однозначно определить, распределяются в корпусе следующим образом: м.р./ср.p. - форма ho (20 примеров); ж.р. - формы jej, jij и ji (соотв. 9, 3 и 1 случай употребления); мн.ч. - форма ix (8 примеров).

то - в отличие от Р.п. - в В.П. эта пара не употребляется ни в литературных формах соседних языков, ни в их диалектах. Если же учесть факт омонимии Р.п.=В.п. в парадигме женского рода, установленной в корпусе на примере наиболее частотных форм jej и n'ej, то появление пары $j i j-n$ ' $i j$ в В.п. можно объяснить распространением на неё омонимии по аналогии с Р.п., т.е. с парой $j e j-n ' e j$.

25 Эта форма широко распространена в малопольских диалектах (Nitsch 1960).

26 Ср. Р.П. мн.ч. 
г) Дате льны й па деж. Употребление анафорических местоимений в Д.п. зафиксировано в исследуемом корпусе только в беспредложном контексте, таким образом, все представленные ниже формы это формы без начального $n$-.

\begin{tabular}{|c|c|c|c|c|c|c|c|c|c|c|c|}
\hline \multicolumn{4}{|c|}{ M.p./cp.p. } & \multicolumn{4}{|c|}{ ж.p. } & \multicolumn{4}{|c|}{ Мн.Ч. } \\
\hline грамм. & корп. & n & $\%$ & грамм. & корп. & $\mathbf{n}$ & $\%$ & грамм. & корп. & $\mathbf{n}$ & $\%$ \\
\hline $\mathrm{mu}$ & $m u$ & 110 & 93,2 & ij & $i j$ & 5 & 8,1 & $\mathrm{im}$ & $i m$ & 38 & 92,7 \\
\hline \multirow[t]{3}{*}{ jomu } & jomu & 7 & 5,9 & & jej & 28 & 45,2 & & jim & 2 & 4,9 \\
\hline & јети & 1 & 0,8 & & $j i$ & 22 & 35,5 & & $y m$ & 1 & 2,4 \\
\hline & & & & & $j i j$ & 7 & 11,3 & & & & \\
\hline \multicolumn{12}{|c|}{ после предлога } \\
\hline \multirow[t]{2}{*}{ n'omu } & - & & & ny & - & & & nym & - & & \\
\hline & & & & n'ij & - & & & & & & \\
\hline
\end{tabular}

Таблица 4. Анафорические местоимения в дательном падеже

Для м.p./ср.p. лемковская грамматика предлагает формы $m u-$ јоти - n’oти. В целом, исследуемый корпус подтверждает предложенную в грамматике парадигму: энклитическя форма ти встречается в корпусе 110 раз, для формы јоти корпус даёт 7 примеров употребления. Кроме того, в корпусе зафиксирован и 1 случай употребления «польско-словацкой» формы јети с тематическим -е-. Во мн.ч. корпус показывает также довольно ясную картину: заданная грамматикой форма im преобладает в корпусе в более чем 92\% употреблений. Наряду с этой формой 2 раза употребляется диалектное йотированное $j i m, 1$ раз встречается и форма $y m$.

Что же касается парадигмы женского рода (и на этот раз отличающейся высокой вариантностью конкурирующих форм), то здесь ситуация складывается куда более проблематично: согласно норме, предписанной лемковской грамматикой, в Д.п. должны употребляться формы $i j^{27}, n y$ и $n^{\prime} i j$. Как уже было сказано выше, употребление анафорических местоимений после предлога (т.е. форм на $n$-) в Д.п. в корпусе не уста-

27 Форма $i j$ является «специфически лемковским» феноменом, т.к. она не встречается ни в литературных вариантах соседних языков, ни в их диалектах. 
новлено, но и форма $i j$ представлена в корпусе очень слабо: она предпочитается только в 8,1\% случаев. Таким образом, парадигма ж.р. в Д.п. корпусом не подтверждается. Более того, её развитие берёт очень неожиданное направление: как видно из таблицы 4, «главными конкурентами» в Д.п. оказываются формы јеј и ji, причём предпочтение с перевесом в $10 \%$ отдаётся форме jej. С одной стороны, появление этой формы в данной позиции означает сближение с западнославянскими соседями, и причём не только с формальной точки зрения (јеj - форма ж.р. Д.п. в польском и словацком языках), но и в структурном плане: благодаря этой форме в парадигме ж.р. возникает типичная в данной позициии для польского и словацкого омонимия Р.п.=Д.п. Но с другой стороны, если учесть результаты корпусного анализа этой парадигмы в В.п., падежный синкретизм, с которым мы здесь имеем дело, «расширяется» до формулы Р.п.=В.п.=Д.п., в результате чего лемковский в структурном плане отдаляется от всех соседних языков и сближается с пряшевским вариантом русинского, для которого также характерен этот специфический синкретизм (cp. Teutsch 2001: 136; Pugh 2009: 81).

Конечно, перевес в 10\% сам по себе ещё не даёт основания говорить о чёткой тенденции к предпочтению в Д.п. формы jej, тем более что формы $j i, j i j^{28}$ и $i j$ вместе составляют больше половины всех употребляемых здесь форм. Но если взглянуть на все выше описанные формы с учётом установленной в корпусе падежной омонимии, то как в парадигме м.p./cp.p., так и в парадигме ж.р. можно выделить по две конкурирующие между собой группы:

1) группы с тематическими гласными -e- и -i- в парадигме ж.p. (jej-n’ej vs. $\left.i j-j i-j i j-n^{\prime} i j\right)$

2) группы с тематическими гласными -о- и -е- в парадигме м.p./cp.p. (joho - n'oho vs. jeho - n'eho - neho и jomu vs. jeтu)

Из таблицы 5 видно, что в корпусе прослеживается чёткая тенденция к предпочтению форм с тематической гласной -о- в парадигме мужского/среднего рода $(88,7 \%)$ и с тематической гласной -e- $(69,2 \%)$ - в парадигме женского рода.

28 Параллельное употребление форм $j i$ и $j i j$ в дат.п. очень распространено как в малопольских, так и в восточнословацких диалектах (cp. Nitsch 1960: 72/ Панькевич 1938: 271-272). 


\begin{tabular}{|c|c|c|c|c|c|}
\hline \multicolumn{3}{|c|}{ м.p./cp.p. } & \multicolumn{3}{c|}{ ж.p. } \\
\hline тем. гласная & $\mathrm{n}$ & $\%$ & тем. гласная & $\mathrm{n}$ & $\%$ \\
\hline -о- & 55 & 88,7 & -е- & 119 & 69,2 \\
\hline -е- & 7 & 11,3 & -i- & 53 & 30,8 \\
\hline
\end{tabular}

Таблица 5. Распределение предпочтений при выборе форм анаф. местоимений в Р.п., В.п. и Д.п. по тематическим гласным

Кроме того, если учесть тот факт, что все приведённые в лемковской грамматике формы для Д.п. ж.р. - это формы с тематической гласной $-i-(-y-)$ и что эта грамматика является своего рода отражением реальной языковой действительности 20-летней давности, то вывод напрашивается сам собой: развитие парадигмы ж.р. в Д.п. направлено скорее всего на вытеснение формой јеј форм с тематическим- $i^{29}$.

д) Творительный падеж. В качестве форм творительного падежа в лемковской грамматике поданы формы с начальным $n$-, которые - как и в других соседних языках - должны использоваться и в беспредложном контексте.

\begin{tabular}{|c|c|c|c|c|c|c|c|c|c|c|c|}
\hline \multicolumn{3}{|c|}{ м.p./cp.p. } & \multicolumn{5}{c|}{ ж.p. } & \multicolumn{4}{c|}{ мн.ч. } \\
\hline грамм. & корп. & $\mathbf{n}$ & $\mathbf{\%}$ & грамм. & корп. & $\mathbf{n}$ & $\mathbf{\%}$ & грамм. & корп. & $\mathbf{n}$ & \% \\
\hline nym & nym & $\mathbf{3 8}$ & $\mathbf{8 6 , 4}$ & n'om & n'om & $\mathbf{3 2}$ & $\mathbf{9 4 , 1}$ & nyma & nyma & $\mathbf{1 4}$ & $\mathbf{7 7 , 8}$ \\
\hline & n'im & 6 & 13,6 & & n'o & 2 & 5,9 & & nymy & 4 & 22,2 \\
\hline
\end{tabular}

Таблица 6. Анафорические местоимения в творительном падеже

Результаты корпусного анализа в целом подтверждают парадигму Т.п., предложенную лемковской грамматикой: форма пуm для м.p./ср.p. употребляется в 86,4\% случаев, форма ж.р. n’om - в 94,1\%, а форма мн.ч. nута - в 77,8\% случаев. Все эти формы согласно грамматической норме употребляются в корпусе как без предлога, так и после него. Кроме

29 Это предположение подтверждается результатами анализа более «раннего» корпуса, собранного в 1994-96 гг.: в нём употребление формы формы јеј составляло всего лишь 22\% от общего числа (ср. 45,2\% в 2010 году), в то время как форма $j i$ употреблялась в 63,8\% случаев (2010 год - 35,5\%). Cм. Menzel/Reis (в печати). 
того, в корпусе зафиксированы случаи употребления «польских» форм n’im в м.p./ср.p. (6 примеров) и n’ $\tilde{o}$ в ж.р. (2 примера). Во мн.ч. 4 раза встречается «украинская» форма путу.

е) М естный (предложный) пад еж. Несмотря на то, что местный падеж представлен в исследуемом корпусе очень слабо, в парадигме м.p./cp.p. всё же прослеживается тенденция к предпочтению формы nym, заданной лемковской грамматикой: она употребляется в 87,5\% случаев (7 примеров). Таким образом в корпусе подтверждается омонимия Т.п.=М.п., характерная и для польского языка. Также зафиксирован единичный случай употребления «польско-украинской» формы $n^{\prime} \mathrm{im}^{30}$. Подтверждается в корпусе и употребление формы $n y x$ во мн.ч. (100\%).

\begin{tabular}{|c|c|c|c|c|c|c|c|c|c|c|c|}
\hline \multicolumn{5}{|c|}{ м.p./cp.p. } & \multicolumn{5}{c|}{ ж.p. } & \multicolumn{5}{c|}{ мн.ч. } \\
\hline грамм. & корп. & $\mathbf{n}$ & $\mathbf{\%}$ & грамм. & корп. & $\mathbf{n}$ & $\mathbf{\%}$ & грамм. & корп. & $\mathbf{n}$ & \% \\
\hline nym & nym & $\mathbf{7}$ & $\mathbf{8 7 , 5}$ & n'ij & $n^{\prime} i j$ & 7 & 63,6 & nyx & nyx & $\mathbf{5}$ & $\mathbf{1 0 0}$ \\
\hline & $n^{\prime} i m$ & 1 & 12,5 & nej & $n e j$ & 3 & 27,3 & & & & \\
\hline & & & & & $n \hat{\imath}$ & 1 & 9,1 & & & & \\
\hline
\end{tabular}

Таблица 7. Анафорические местоимения в местном падеже

Что же касается парадигмы ж.р., то вариантность, заложенная уже в грамматике, продолжается и в корпусе: 7 раз в нём употребляется форма $n^{\prime} i j$, а для формы nеj (с твёрдым начальным $n$-), встречающейся в корпусе впервые и только в этой позиции, нашлось 3 примера употребления. Кроме того, зафиксирован один случай употребления формы $n \hat{\imath}$, встречающейся в малопольских диалектах (Nitsch 1960: 114). Конечно, ввиду слабой представленности местного падежа в корпусе, очень сложно делать какие-либо выводы о тенденциях нарастания или убывания вариантности, победе одной из этих форм или их равновесии. Но, поскольку (1) для всех славянских языков характерен падежный синкретизм Д.п.=М.(П.)п., и (2) во всех парадигмах ж.р., показывающих конкуренцию между формами с тематическими гласными -e- vs.

30 В украинском языке эта форма постепенно вытесняется альтернативной формой n'оти. 
-i- (т.е. в Р.п., Д.п. и В.п.), в корпусе наблюдается тенденция к предпочтению форм с тематическим -e-, то наиболее «ожидаемым» в этой «клетке» было бы появление формы n'ej (причём с палатализованным $n$-, как и в Р.п., где корпусная форма n'ej вытеснила заданную грамматикой форму пеј). В этом случае в парадигме ж.р. имела бы место «специфически лемковская» падежная омонимия Р.п.=Д.п.=В.п.=М.п. $\left(j e j-n^{\prime} e j\right)$. Если же вопреки всем прогнозам в парадигме сумеет закрепиться форма $n$ ' $i j$ с тематическим -i- (употребление которой в корпусе носит скорее спорадический характер и поэтому в структурном плане не оказывает никакого влияния), то аналогичную тенденцию можно будет ожидать и в Д.п. (в противном случае М.п. в парадигме ж.р. будет относительно обособленным и не будет участвовать в падежной омонимии) - пока же развитие там протекает в пользу форм с тематической гласной -e-, т.е. в противоположном направлении.

\section{3. Заключение}

В ходе исследования было зафиксировано наличие некоторых расхождений между описанными в нормативной грамматике правилами употребления анафорических местоимений в лемковском языке и реальной языковой действительностью. Проявляются они, с одной стороны, в характерной для корпусной парадигмы высокой степени вариантности конкурирующих форм (особенно в парадигме женского рода), с другой же стороны, в результатах преференций при выборе форм. Несмотря на то, что в большинстве случаев высокую вариантность в корпусе можно «устранить», учитывая только наиболее частотные варианты, варианты эти в некоторых случаях всё же отличаются от форм, заданных грамматикой: либо прослеживается чёткая тенденция к преференции только одной из двух (или нескольких) форм, представленных в лемковской грамматике (напр. Р.п./В.п. м.р./ср.p.), либо же предпочтение отдаётся совершенно «новой», не указанной в грамматике форме (как в Р.п./Д.п. ж.р.). 


\begin{tabular}{|c|c|c|c|c|c|c|}
\hline \multirow{2}{*}{$\begin{array}{l}\text { род } \\
\text { пад. }\end{array}$} & \multicolumn{2}{|c|}{ м.p./cp.p. } & \multicolumn{2}{|c|}{ ж.p. } & \multicolumn{2}{|c|}{ мн.ч. } \\
\hline & грамм. & корпус & грамм. & корпус & грамм. & корпус \\
\hline И.п. & v'in ono & v'in ono & ona & ona & ony & ony \\
\hline Р.п. & $\begin{array}{c}\text { ho, joho } \\
\text { neho, } \\
\text { n'oho }\end{array}$ & $\begin{array}{c}\text { ho,joho } \\
\text { n'oho }\end{array}$ & $\begin{array}{l}\text { jej } \\
\text { nej }\end{array}$ & $\begin{array}{c}\text { jej } \\
\text { n'ej }\end{array}$ & $\begin{array}{c}\text { ix } \\
\text { nyx }\end{array}$ & $\begin{array}{c}\text { ix } \\
\text { nyx }\end{array}$ \\
\hline В.п. & $\begin{array}{c}\text { ho, joho } \\
\text { neho, } \\
\text { n'oho }\end{array}$ & $\begin{array}{c}\text { ho,joho } \\
\text { n'oho }\end{array}$ & $\begin{array}{c}\text { jej, ju } \\
\text { n’u }\end{array}$ & $\begin{array}{c}\text { jej } \\
\left(n^{\prime} e j, n^{\prime} u\right)\end{array}$ & $\begin{array}{c}\text { ix } \\
\text { nyx }\end{array}$ & $\begin{array}{c}\text { ix } \\
\text { nyx }\end{array}$ \\
\hline Д.п. & $\begin{array}{c}\text { mu, jomu } \\
\text { n'omu }\end{array}$ & $\begin{array}{c}\mathbf{m u}, \mathbf{j o m u} \\
(\text { n'omu})^{\prime}\end{array}$ & $\begin{array}{c}\text { ij } \\
\text { ny, n'ij }\end{array}$ & $\begin{array}{c}\text { jej, (ji) } \\
\text { (n'ej) }\end{array}$ & $\begin{array}{l}\text { im } \\
\text { nym }\end{array}$ & $\underset{(n y m)}{i m}$ \\
\hline Т.п. & nym & nym & n'om & n'om & nyma & nyma \\
\hline М.п. & nym & nym & nej, n’ij & nej, n'ij & nyx & nyx \\
\hline
\end{tabular}

Таблица 8. Формы лемковских анафорических местоимений из нормативной грамматики в сопоставлении с формами из узуса лемковской речи

Причём в некоторых случаях вариантность свойственна и самой грамматике, которая, в свою очередь, носит скорее дескриптивный характер (по крайней мере, морфологическая часть) и представляет собой попытку систематизации знаний о языке. Особенно чётко это проявляется в том, что представленные в ней флексионные парадигмы нередко являются избыточными: для них также характерна вариативность, т.е. наличие в одной «клетке» дублетных форм, не несущих никакой дополнительной - в данном случае - семантической или морфосинтаксической нагрузки (как, напр., в Р.п./В.п. м.р./ср.р. и в В.п./Д.п./М.п. ж.р.), что, в свою очередь, только усложняет кодификационные процессы ${ }^{31}$. Не удивителен поэтому и тот факт, что именно эти клетки с дублетными формами и в корпусе оказываются «проблематичными». Как видно из таблицы $8^{32}$, составленной на основе корпусного анализа, в 5 из 18 «клеток» набор форм, зафиксированных в корпусе, не соответству-

31 Ср. замечание Дуличенко по этому поводу (Duličenko 2009: 138). О проблемах, связанных с кодификацией см. также Fontański 2008: 50-56.

32 В таблицу 8 вошли только наиболее частотные, т.е. предпочитаемые в корпусе формы или «пары» форм. Формы, представленные в скобках - это формы (1) постепенно вытесняемые конкурентами или (2) дополненные по аналогии (как, напр., в Д.п.). В серых клетках представлены наборы форм из грамматики и им 
ет набору форм, предписанных грамматикой. И если в случае с парадигмой м.p./cp.p. речь идёт о своего рода «оптимизировании», или коррекции парадигмы, - в Р.п./В.п. при достаточно чётком распределении преференций убирается одна «лишняя» форма (neho) - то в парадигме ж.р. всё выглядит гораздо сложнее: судя по всему, в данный момент она находится в процессе языкового изменения, индикатором для которого являются высокая вариантность конкурирующих форм и нечёткие преференции. Но тем не менее и здесь анализ корпуса позволяет выявить одну довольно неожиданную тенденцию: распространение форм с тематическим -е- в Р.п., В.п. и Д.п., а именно явное предпочтение пары јеј - n'ej в Р.п., явное предпочтение формы јеј в В.п. (в предложном контексте всё ещё доминирует $n^{\prime} u$ - здесь процесс языкового изменения ещё «в самом разгаре»), а также появление формы јеј в Д.п. рядом с формой $j i$ с тенденцией к предпочтению формы jej, которая подтверждается и во временной перспективе. Таким образом, корпус показывает специфический падежный синкретизм Р.п.=Д.п.=В.п.(ж.р.). Присоединится ли к нему когда-нибудь слабо представленный в корпусе М.п.(ж.р.), покажет время. Пока же ясно одно: состав флексий, предписанный нормативной лемковской грамматикой, составленной около 20 лет тому назад ${ }^{33}$, больше не является адекватным отражением репертуара форм анафорических местоимений, употребляемых в речевой практике носителей лемковского языка ${ }^{34}$. Причиной этому послужил, вероятно, всё ещё активный процесс языкового изменения, обусловленный как внутренними, так и внешними факторами. Не исключены в данном случае и определённые предпочтения кодификаторов - авторов грамматики,

соответствующие формы/ наборы форм из корпуса; жирным шрифтом выделены формы из корпуса, тенденции к предпочтению которых чётко прослеживаются.

33 Парадигмы анафорических местоимений из грамматик 1992 и 2000 гг. совпадают. Ср. прим. 9.

34 Как уже было сказано выше, грамматики региональных вариантов русинского языка должны были базироваться на «живой» разговорной речи соответствующего региона. По словам проф. Фонтанского - соавтора лемковской грамматики - представленные в грамматике формы были верифицированы не только на языковом материале из различных письменных источников (см., напр., Fontański 2007: 116-118), но и в среде носителей языка - лемковской интеллигенции (ср. также Фонтаньскій/Хомяк 2000: 12) - с помощью анкет (ср. Рыдзанич 2013: 54) или же устно во время проведения Лемковской Ватры в Ждыни. 
выражающиеся в введении в парадигму уже устаревших или «искусственных» элементов (возможно, не принятых носителями) и нацеленные на отталкивание от соседних языков (здесь - от украинского, польского и словацкого) или же сближение с ними. ${ }^{35}$ Кроме того, следует обратить внимание также и на то, что в данном случае вполне возможны расхождения между устным и (более подверженным влиянию кодифицированной нормы) письменным узусом. Но нельзя забывать, что кодификация - это сложный и долговременный (а в данном случае - ещё не законченный) процесс, и поэтому нужно отдать дань авторам лемковский грамматики - «первопроходцам», проделавшим в этом процессе нелёгкий путь. Возможно, проблематика, поднятая в данной статье, поможет кодификаторам принять в будущем то или иное решение.

\section{Литература}

Дуличенко А. Д., 2006, Современное славянское языкознание и славянские литературные микроязыки, в: А. Д. Дуличенко, С. Густавссон (ред.), Славянские литературные микроязыки и языковые контакты, Тарту: Slavica Tartuensia VII, c. 22-46.

Жовтобрюх М. А., Волох О. Т., САмІйленко С. П., Слинько I. I., 1980, Iсторична граматика украӥнської мови, Київ: Вища школа.

ЛАтта В., 1991, Атлас українських говорів східної словаччини, Братіслава-Пряшів.

МАгочій П. Р., 2004, Этно-географічный і історічный перегляд, в: Р. R. Magocsi (ред.), Najnowsze dzieje języków słowiańskich. Русинскый язык, Opole: Uniwersytet Opolski - Instytut Filologii Polskiej, c. 15-38.

ПАнькевич I., 1938, Україньскі говори Підкарпатської Руси і сумежних областей. Звучня і морфологія, Прага.

PІгер Я., 2004, Становиско і зріжницюваня «русинскых» діалектів в Карпатах, в: Р. R. Magocsi (ред.), Najnowsze dzieje języków słowiańskich. Pусинскый язык, Opole: Uniwersytet Opolski - Instytut Filologii Polskiej, c. 39-66.

Рыдзанич А., 2013, Лемківска силачка, Przeglad Prawosławny 10 (340), s. 54-55.

Филин Ф. П., 2006, Происхождение русского, белорусского и украинского языков. Историко-диалектологический очерк, 2 изд., Москва.

ФонтАньскій Г., Хомяк М., 2000, Іраматыка лемківского языка. Gramatyka języka łemkowskiego, Katowice: Śląsk, WN.

35 Об этой проблематике см. также Fontański 2008. 
Хомяк М., 1992, Іраматыка лемківского языка. Морфольотія і ортотрафія, Лєгніца: Стоваришыня Лемків.

DuličEnKo A. D., 2009, Das Russinische, in: P. Rehder (ed.), Einführung in die slavischen Sprachen, 6. Aufl., Darmstadt: WBG, S. 126-140.

EWJP: Urbańczyк S. (red.), 1978, Encyklopedia wiedzy o języku polskim, Wrocław: Zakład Narodowy im. Ossolińskich.

FontaŃSKi H., 1997, Odmiana rzeczowników we współczesnych łemkowskich tekstach pisanych, w: H. Fontański, M. Blicharski (red.), Współczesne tendencje rozwoju języków słowiańskich, t. 2, Katowice: WUŚ, s. 116-139.

Fontański H., 2008, Aktualne problemy języka łemkowskiego (normalizacja pisowni), в: А. Плїшкова (ред.): Русиньскый язык меджі двома контресами. Зборник рефератів з III. Меджінародного контресу русиньского языка, Краків 13.-16.9.2007, Пряшів, с. 50-56.

KURASZKIEwICZ W., 1954, Zarys dialektologii wschodnio-stowiańskiej z wyborem tekstów gwarowych, Warszawa: Państwowe Wydawnictwo Naukowe.

MAGocsi P. R., 2006, Русинский язык: достижения последнего времени и предстоящие задачи, в: А. Д. Дуличенко, С. Густавссон (ред.), Славянские литературные микроязыки и языковые контакты, Тарту: Slavica Tartuensia VII, c. $207-222$.

Menzel Th., Reis A., (в печати), Regularität/ Irregularität im Paradigma anaphorischer Pronomen - Lemkisch zwischen Polnisch, Ukrainisch und Slowakisch, Zeitschrift für slavische Philologie, Heidelberg: Winter Verlag.

Michna E., 2004, Kwestie etniczno-narodowościowe na pograniczu Stowiańszczyzny wschodniej i zachodniej. Ruch rusiński na Stowacji, Ukrainie i w Polsce, Prace Komisji Wschodnioeuropejskiej VIII, Kraków: PAU.

Misiak M., 2006, Łemkowie. W kręgu badań nad mniejszościami etnolingwistycznymi w Europie. Wrocław: WUW.

Nitsch K., 1960, Wybór polskich tekstów gwarowych, Warszawa: Państwowe Wydawnictwo Naukowe.

Pugh S. M., 2009: The Rusyn Language. A grammar of the Literary Standard of Slovakia with Reference to Lemko and Subcarpathian Rusyn, München: Lincom Europa.

RABUS A., 2011, Untersuchungen zur sprachlichen Variation im Karpatorussinischen, Zeitschrift für slavische Philologie 68/2, S. 421-439.

Teutsch A., 2001, Das Rusinische der Ostslowakei im Kontext seiner Nachbarsprachen, B. Panzer (ed.), Frankfurt: Heidelberger Publikationen zu Slavistik 12.

Townsend Ch. E., JANDA L. A., 2002, Gemeinslavisch und Slavisch im Vergleich. Einführung in die Entwicklung von Phonologie und Flexion, P. Rehder (ed.), München: Slavistische Beiträge 416. 


\section{Lemkian anaphoric pronouns: \\ the codified norm vs. spoken language usage \\ ( summary)}

This article describes the main tendencies in the development of the Lemkian morphology, namely, in the inflection of the anaphoric pronouns in the speech of Lemkos. The focus is on determining similarities and differences between the inventory of grammatical forms, as described in the codified norm, and the pronominal forms, the use of which is typical for the actual spoken Lemkian (presented here as a corpus of Lemkian oral speech, consisting of conversations recorded within a family circle). The present comparative analysis shows that the paradigm of anaphoric pronouns in the Grammar of Lemkian language is no longer an adequate reflection of the linguistic reality. 
